経営史学

考れがさ員す

えたと云らのる今

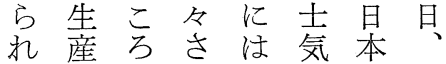

る 管でれ ア がの 日

加理、るフ秀経本

も无欧わ夕机党的一

しあ米け Iて管経

れり、人でサい理営日

な、があ!省組㤎本

的こ 日 る ビ各織 欧 本

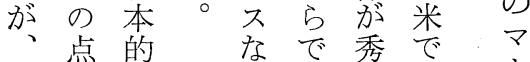

マ妿経年あれ高!

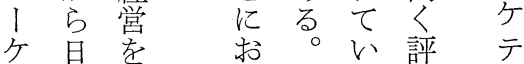

テ本評い逆る価イ

の価 てにとさ

ン $\mathrm{Q}$ す \&

グ C る 秀えれる

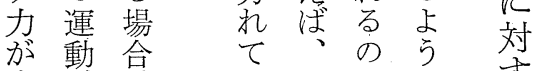

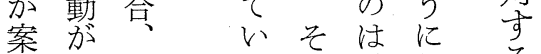

外高、特るのる る

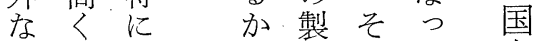

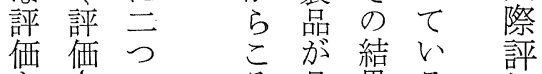

をさの品果る価

早 文

う点、質とが

讨てに注学标終

いる自よい具身

る。し うて体㕍

つて \& 化傭

もいい製価さ制

ちでる品格れ

ろ第。をにる年

ん第 生お製功

こはばたのの列

の、 寸 質 制

場早 ら

の人ま企た痖議

マにで業デ性制

○ともの゙芰

ケっな経イあな

テてく、営う る ど

ン意そ理耐は特

グ多の 能久従徽

力と秀力性業と

鳥

羽

欽

郎 


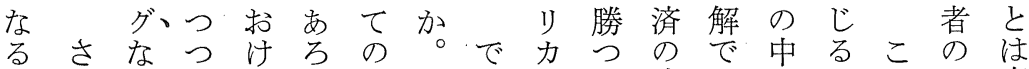

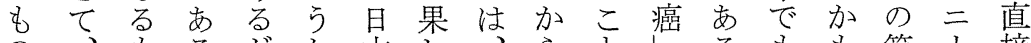
の、もる怔か本し、らと第接 がこのと如。のてこ懸はでば指し云市の

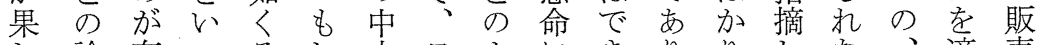

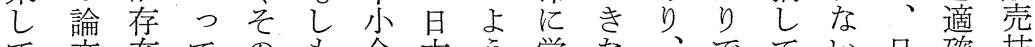
て文在てのも企本う学ないでてい確技

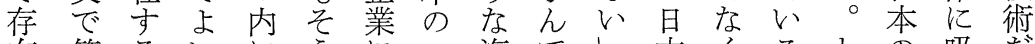
在筆るいにうにマ海でし本くるとの吸た 寸者との隠だつ、外きと企、よいマ収け るがもかをとケでた 固業戦うう、しを の解いも的亦てテののく後にのケて意 か明いしたるのイ評が信つのの、はテ製味 、しうれ強な議ン価日じい流早、イ品す もよるなるるら論グと本らら通早たン計る しうのいを祀やは早でれ早龩本とグ画も 存とでの秘、日遅本あてく新の市力にの

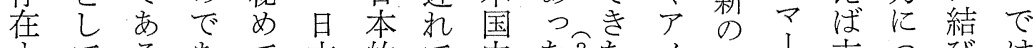

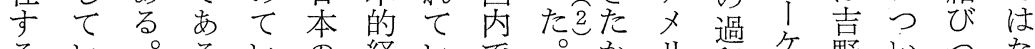

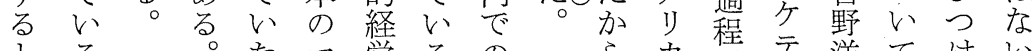

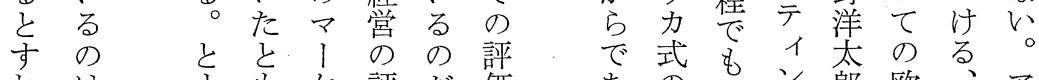

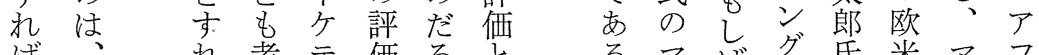
ば、れ考テ価ろと

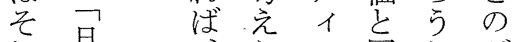
れ早梠ン同加ギ

は本的机グ様。ヤ ぞ経本、は そ の整的そ必今れプ よ吕経机ず日と沙

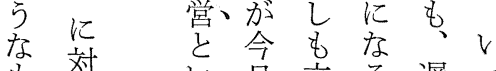

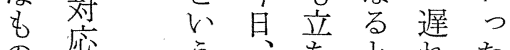
の衤呼マ遅逆杂た ある称!机にいど る意にケててるの の 喿なテい強とよ かららくたさ考ら とのンののた い昌、てグで秘ら考 う早、先は密れ光 的進な礼た

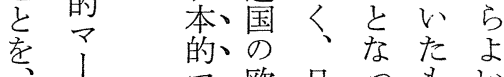

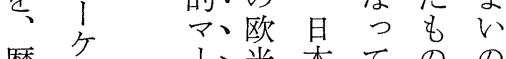

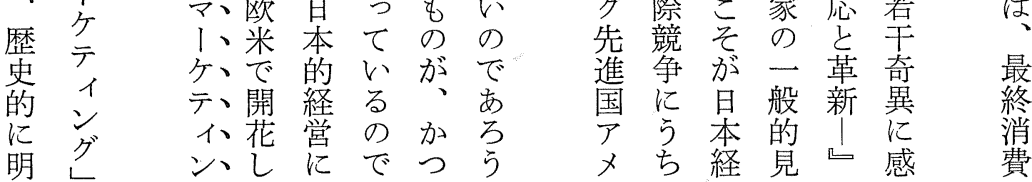
るマばグ氏米マフ 。1沙人名、 そケ注まその方、 しテ主だの評テサ てィ㸟著秀価イ!

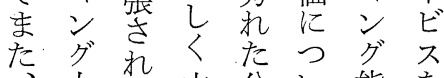
力た立分能を そを学析て力爷 の身 う遅可将含 たにに光旦、含め めつ婂本わ字た にけワいのれれ、物 こな流るマわる、流 そ、通保机。的 限過と宁一側 マり程いテ般面 I、管 ケ跾 立 の ィい遅専!人只 ン国れ門適はに 
経 営史 学

\section{[一]今・な代 今}

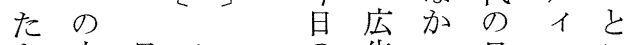

と中日 七

えの 本

経最語儿代術にに理で

験 終で ス

的段は。

な階趾文

も賠玄

でな 管 メ

あわ理ン

た 貾呼氙

てをれ

如

戦にる

前 巧 \&

の み の

日にで尔

本まあ

はたる。

\& 効

ち率こ

万的れ

んには

行 販

江 5 売

戸五

時と ネ

代いジ

のうヤ

商技 !

家術の

にで実

おあ務

いる。技

\&そで

極て あ

めこ、

て発技

達術

しな テ

て 51

たばン ダ
の告っ日ンこ

近技た本グろ

的な術にに理で

マ 点よ， I

ケ存今 ケ 影

テ在日ィの の

1しのン下イ

ンてマグにンケケ

グい、がお グ テ

のたケ存いと

概こテ在てい

念とィしでら

分をは方な゙ かっ用

類ちのつた㤎

杽ろ概た。目

るん念とし本

とでに心加に

以る炰 こ摂ここ

市。挎 こ こ

のこれでこ格

三のるはと的

つよ販なはに

のら壳い、定

段な管。明着

階日理た治与

に本、と時る

区在さえ代よ

分来ら方ら

劣のに、らに

るマはケのな

こ1 在テ 戦 つ

そケ董ィ前た

でィ理グ日は

きン方と本

る3

学物方さ後

そ流呼ら 称に

発市ではメ

展場呼遡リ

段調 ばつ力

階香れての

に罗江?

即宣は辛

し、伝以時 ケ
か面、定 スら

にですにか

すあるつに

るる伝いす

ここ 統、て る

二 京 こ 的、検 こ

こ デで あ

ののあゆる

論側り、く

文面第 こた

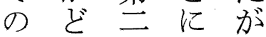

筆のはすつ

グ 者よ 、るて

和課に旦々以

和題絡世の市

でみ界場 日

あ合芯合本

るい評、の

、価議 マ

そさ論!

て

今 いつ

日るにン

のこ分 グ

日とけの

本でる。歴

の\&。史

又 明第的

I 万一特

ケかは質

テな

$\begin{array}{lll}1 & よ & \text { 日 } \\ \text { ๖ } & \text { 本 }\end{array}$

グにの格

特国

質際尔

けにイそ

て共ンの

い通グ近

る军文代

のる歴化

加近、史 の

老代的 $7^{\circ}$

明的、に口

ら側、規 セ 


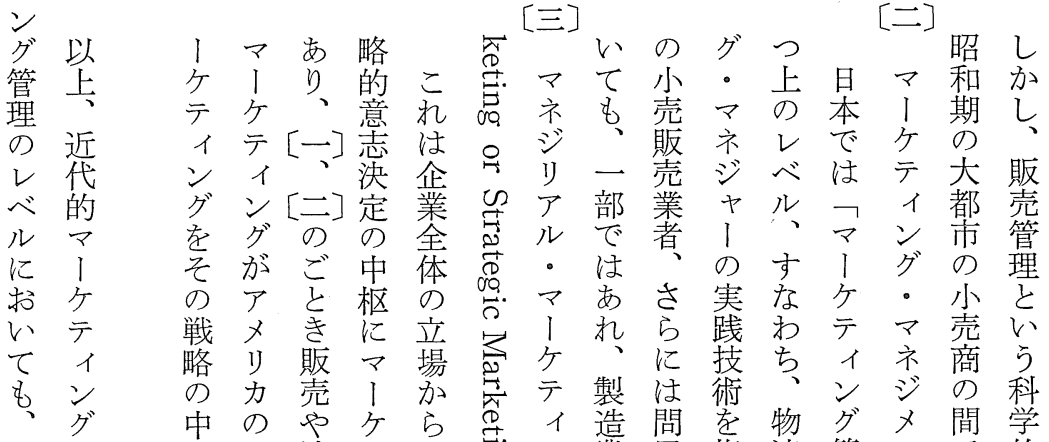
江 心そ流テ す 志 ン 業 屋指 流管ン で的

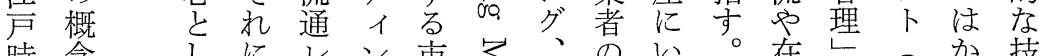

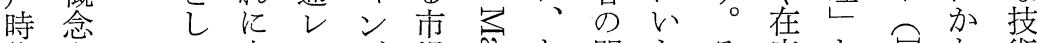
代妾て 立べグ場吉あ間たそ庫と客な術

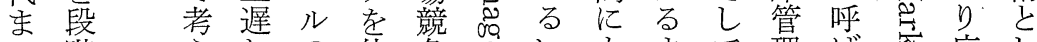

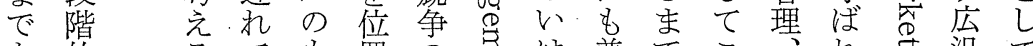
を的 る

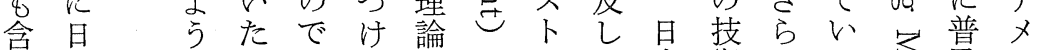

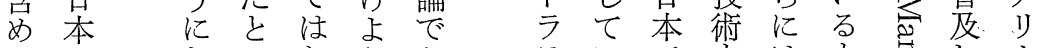

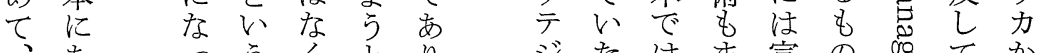

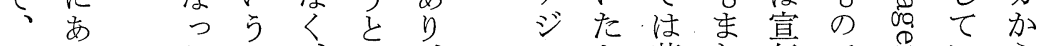
戦てたの、守、著た伝で怘いら

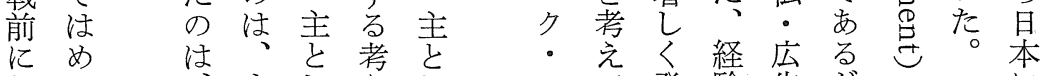

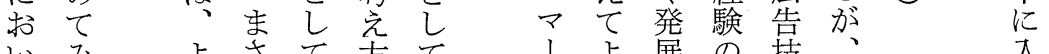
いみささて 方て てるらに製は経らないし蓄術これる

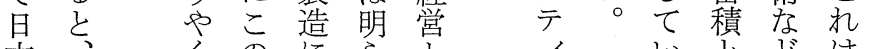

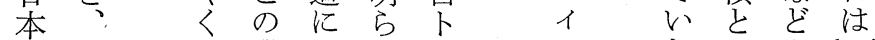

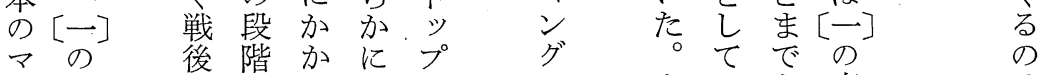

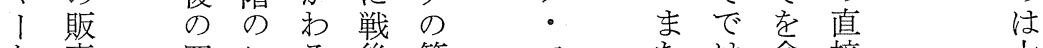
ケ党 四こ学

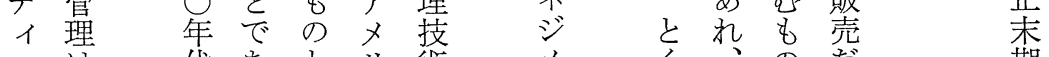
ンは代あをと少術 メ く

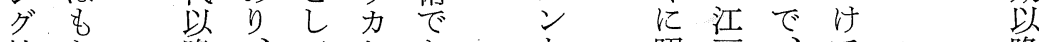
技ち降、て か あ、昭戸 ト 降 術ろ の. 日把らる 和時今な の 加[云] 点

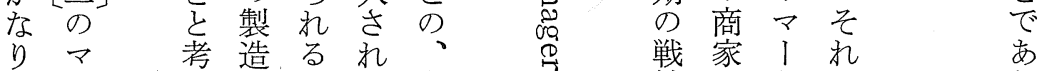

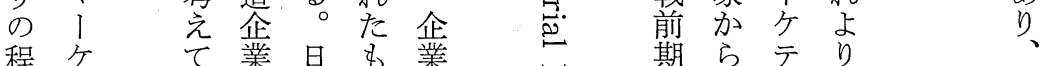

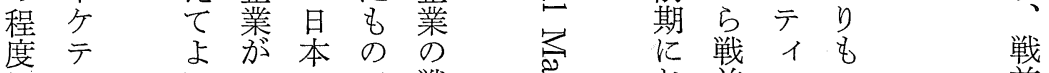

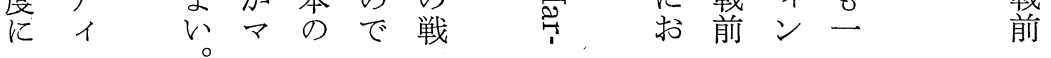




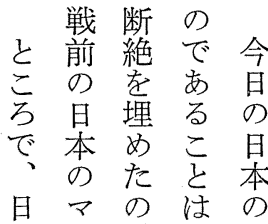

$\begin{array}{lllll}\text { 日 } & \text { 本 } & \text { 1 } & \text { が } & \text { 明 }\end{array}$

のケ 戦ら !

マテ後少

Iイのでテ

ケン流あ、

テ グ 通 る ン

基新し が

グ本 加戦

基な近な 力

本性代吕

的格的 50

な特発裓衣

徴展ケ前の

は形 テ 亡 延

、態イ戦長

そ辛ン 後線

当技掠に

初以術以亦

加下

ら必導は吋。

国要 祭そこ

際な的

マ㔔ぎ間字

ケりあ大正

テ 簡つき ・

1単たな近

ンに亡断代

グ素考絶 化

と描えがさ

国してみ开

内文 5 な

マ文的方

1 るいる

ケことそそ展

1にこLL

ンすでてて

グ る ま ま
差こ閴メま屋リたたたるがにり、ま 基よ制力そだ考あおむ発 盤う度に机、方っきし展 をな为おをアらたからし 求問代以補メ机に爫

三め屋替て て制し小も力。る み口熟 よ度た売のに い学と企とお よ中心業しけ ら心 に亡こW 思し亡し商れ わただ製 社と れ流亦造变比 る出通 る 企含 較

機。業め加た

のた果問の

複肪し屋大

雑ったのき

性て、物な

之、! 流差

日 厅機異

ま本テ能枋

たのイ方

○マン 極 製

こ ケ グ め 造

問 市能発業

屋イの達の

の $ン$ 多 ᄂ

果グくて

しの起方

た日た玄

特本かこイ

别的わとン

のなつで グ

マ特て あ が

I質、る 著

ケ劣精。兄

テ見維いく

1 出な

ン守形加遅

グとで文

機す組るて

能る織ない

にな化らた

そ ば れ
日 と パ

本、に

の [一] 近た

売 場 形 考

- 合 で

物 の 機て

流百能よ

技貨的以

術店分。

壮化、

か [三]加ま

なの定こ

$り$ 場着の

の 合 L [-]

発のて

展 問 以[三]

成 に 日 兰

果 文本 の

をらの段

示れ 場 階

七 る 合学

いら考 機

たにえ能

ば、て、的

力科、統

り学 小合

で性売方

なと販以

く、尣ち

-5早

には位

広ま製だ

くだ造 ア

普尔究义

及情、

乙るう力

てとど ど 異
小の w

号屋たむ

船点物 流進 

策銅う同で市采 以物 線ど産は発向商旦学治国年場自亡治亡 にの物、展け社本は政際て 構然は初区

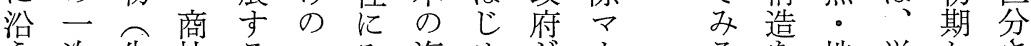

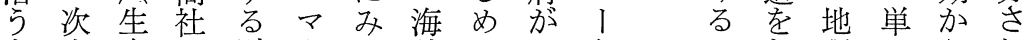
も産系の財 $ら$ 外とそケこな理にられ の品・担閥ケれマ宁のテし的目併て で茶っ系テる|る最ィ存出 あつなたのイよケ貿初ン゙す件がし発

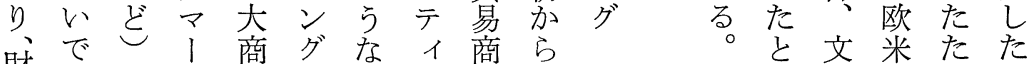
財で第の ケ 社を 商 ン 社 海 閥 第 の ケ䄖 テ劣 専 ン゙社 海 系諸出イ念そ商を、あ貿 企製でン頭れ社主り、易 齒造あグにぞ体、皆 羓志り、の沶さ的次力 発業、目いののらに第を 展製つ的て形に担に学 に嵒で何察担群たのて 伴の、㴎当小碚だ こ輸国あ進しのは動こ て出策っぬた商商のと い市にたる。社社幅は わ場沿のこしがでを周 ば開つでとかああ拡知 そ拓てあにしるつげの ので育ろ、ずたて事 マあ成 うるこ立実

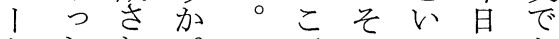
ケたれ。机のつのあ テった はいて総る。

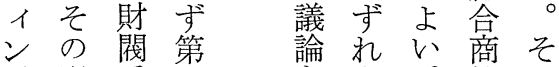
グ限系—を社の 担り諸は単がこにた 当で企、純日のとめ 部、業々 化本商成に 門商のの の 社長設 の社製初 るににし立 役の造期たと注たさ 割活品にめる め的 学動 果は初政のは閥の展 しあ期府 ち異系限し たくにの質商りた の市は石針総の、社で、の

あ 炭に商海関明三 る国・浴社外西治井 い化 先め, と う・進、い こ消諸そう ぞ費国れ貟 そ あ習対れで るのしにあ で垬後つ異る。 は、発たい 次あ資マい にる本 I か 、主ケえ そは義テ・る の政国イな そ府でンら れのあグば 毞つ的

れ針た対海 のなと応外 市どを市 場種 う余場 そ々 こ儀 と そ理ばく内 れ由爫さ市 ににりせ場 対よでらと 応つなれい してくたら た隔、と性 マ離海、格 1 外うの テれ、市こ異 イ 明場で こ ンら国あつ グか内るの にな市。市 $つ$ 三場こ場 
経 営史学

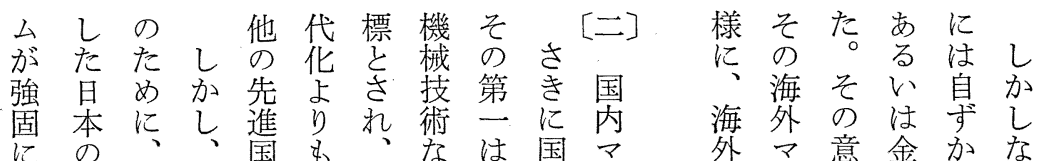

存伝そ右と伝あど政内、市、味融らが

続統のの゙比統らに府市ケ場ケで的限ら

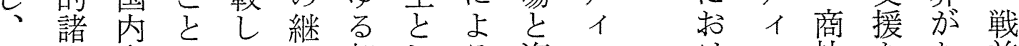

し産市きて承部しる海ン けン社をあ前

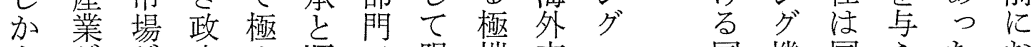

も唯唯府め順で限端市

十長本のて次の定な場

分期質政閉的伝さ国

にに的策鎖な統枳内は

そわに的改産—市早

のた閑かな革菜銷り場本

能て性で場㚙維消護は

を維のな状々持費政截

果持強々況の文財策然

し・文唯工育のでと

え存も欧続業成輸あ区

て続の米く登と入り、分

きしでとこ展がは、さ

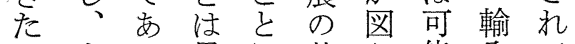

こまつ異に基ら能入て

そたた質な調れな竌な

をそこのっとた限䚄た

みの学たたな。可業と

を流否学可こ制国述

明機めの少よさ建た

ら構な伝なうれ設が

かに統

でお。社主事。近そ

るての方戦加た化原

。导

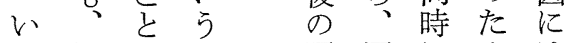

、江は旦昭国にめは

加戸、本和内国に種

光時々の四市内掔多

る代く文 ○場自急の

な以に化年は給にも

ら来消的代急体必の

ばの費。に速制要が

問財地至なのな考

国屋孝理変維原え

内㐫中的玉革持材

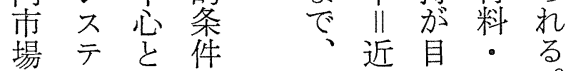

国、機国えた お

問、担のさそて

屋当第占こ注

機と次 は者

能し産輸国の

をて品出内技

果 の生向の術

寻役産き第的

も 割 者の二限

の老商次界

で果第品産 か

あし文に品ら

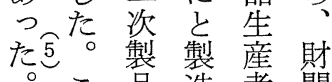

こ氉造者簢

ょ造 の 問

う業指屋企

な者導さ業

味 加行 製

で工うに造

は業なは守

、者ど中る

商のに小王

社オよ製 業

はルつ造製

国ガて業品

内ナ、者と

市イそ。

場ザの加艺

おで外業主

けあ輸者

るる出をそ

問とに組の

屋々努織輸

局江し出 


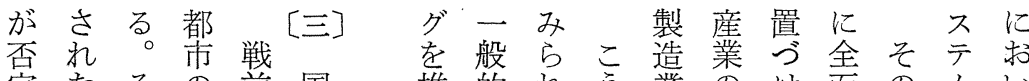

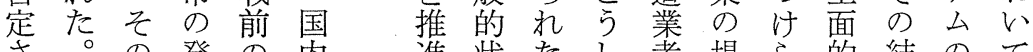
さ。の発の内進状たし者場ら的結のて

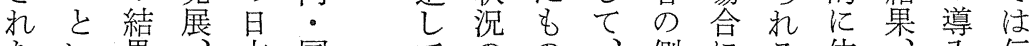
たい果、本国てのの、側にる依大伝 わっと中に際い中の戦加抒存輸と統

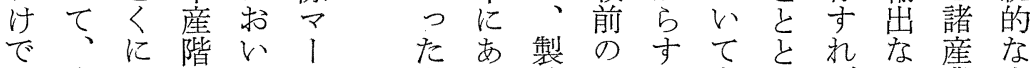
は海小級てケをつ造日るもなばい業産 な外売のもテのて業本積、っよしの業 以市業増、驾、者に極商たか国そと

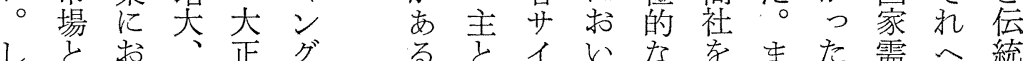
しと挍正グるをイいな学また需へ統 た国い経。ををしドてマ含たた要の的

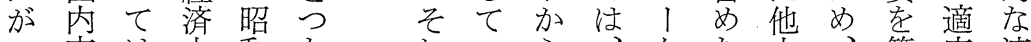

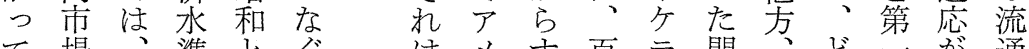

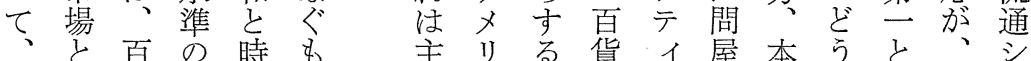

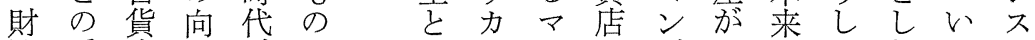
閥乘店上がしか、ののグそなてたわテ 亲離治進 近とチよむ 代そエるに 的こ1 社 $つ$ 企にン会れ 業就有て は隹卢活、 ち、商な西済 万社 ぞ欧的 几の方化変 の優出 $\frown$ 化 こ位現亏に 之一个伴 妘まてフ 統 た、・社 諸 国近 ス 会 沗 代夕変 業市的イ化 に場マ ルが おに I の進 、お亦変行 て け テ 、閎ン゙な゙ 了制手吕と ケ度法元光 テの唯机 ン 存導でな てらケよののらも財ばム 近テう展機妓嶊同が 日代イな開能、術系時残 本的ン小はを!優企併存 でマグ売殆代ケ先業行。 は、はサん替テの的存 伝々著イぞ寻ィ経政に続 統テしドみるン営府行し 産イくから場グに采わ続 業ン立ら机合がな企机忊 にグ遅のなが重り業たた

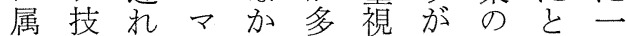
し術る1っかさち場い方 なをこケたつるで合つで 、導亡テのた心゙あて、 新大にイでたきりはよ海 製乙なンあめ国、、、外 品、つグる、内マその市 の積たの。ア市|ので場 製極。発入場ケマあ江 造的し展少学

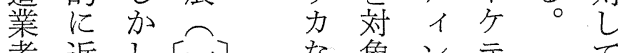
者近し[元]代な

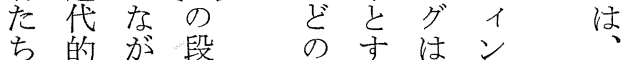
でマら、階場る第グ新 あ 「こは合伝美機能充

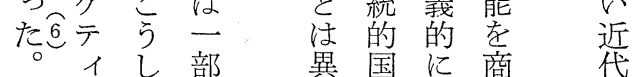
ンたに方位社法 
経営史学

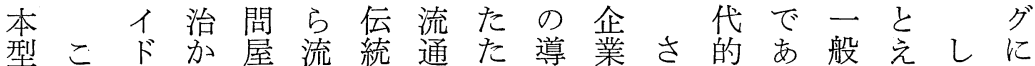
にらのら自通的風め入家ら文り、消ば加対

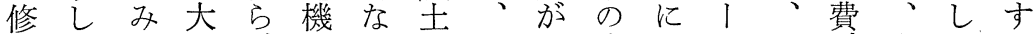
正てな正㤎構 問にそ二多まケこ財生そる

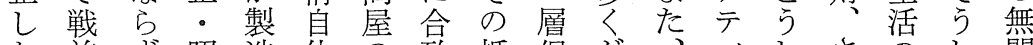
な前ず昭造体の 致抵促が、イしさのし関 がの、和にの中季抗進アこンたら洋た心 ら日主期進近にるるをさメらグ製に風中さ 発本と出代も形排れ机し手造は化では 展にし至し化、で除る力た法業家に依 さおてるてに国そ市こな新孛者庭伴伝然 せい新国、乗分のるとと製積は用つ統と てて製内製り商マこに海品極そ電て的し ゆは㗊市造出店|とな外の的の気新なて く、を場・亦製継 企海製の販も明テ容たのく導場品い造続 業外造変売の治、易。経は大開、市業し

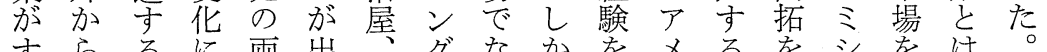
すらるに両出、グなかをメるを゙をは で近 製 伴機現丸手かし生りこ旧ン、開無 に代造つ能し善法つなか力と来、拓関 出的企てをたなのた斿しでにのて係 現マ業、同ばど修ばらて開よ問してな 乙 いテイ イ的業でち余で前活れれて依転た製 たイドマ内在な儀なに動た新存車化を

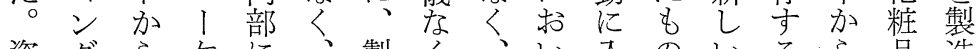
資グらケに、製く、い大のいるら品造 生を导テ統た造さ一てつ加企こ自、导 堂導、ィ合と企れ時はた多業と動キる 大着ン守え業た的依たく発が車ヤ新 森し実グるばにのに然め、展困とンし 永てにのも医対は問と、まの難い方い なこ進展の薬すい屋しアた途でった製 どれ行開も品るら制てメこをあた。造 にをしは現業才ま度問少れ開つ耐洋企 み百て、れ界ルで老屋力ら拓た久菓業 ら本い百るにガも利に的のした消子㔔 れのっ 貨にみなな用よ流た 新て め費類発 よ通の学っ ザ。た流代品く主の洋等 う状で筆たる、しり通マののこ製酒る な況あ頭。よ機か、支 製とし造济よ 流にるとう能しあ配々造にて業医う 通適。专に向る驾テになア者薬に 系合るが、強時い強イ乗つメた品な 路さ小つ伝化には固ンりたりちとっ

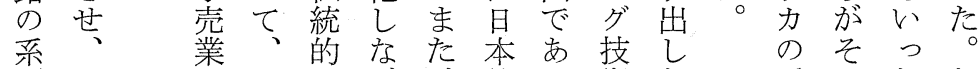
列日省明な夯、的つ術たた近れた 
第ア 況いをべ

にメ戦に う文就ル こ

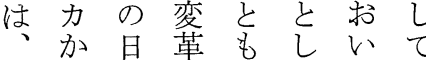
戦ら本をあてて 後近の无つ近 \& 戦 の代マたて代十前 技的 15 、的分 術マケしアマに日 革 | テたメ|出本 新ケイのリケ現に のテンがカ新テしお 結イグ、にイてい 果ンの戦おンいて とグ近後けグたも し理代のるのの近 て論化技が展で代 家吕を術如開 あ的 電積も革きをるマ 製極た新近は帒! 品的らに代じ、ケ -にし伴的め国テ 自導たうマて際イ 動大原早少市市 ン をれと経テ新との は、し済イ製国萠 じてのン品内芽 め売は国グ・市は と企、際の標場

寸業い化全準文小 るのく芯般化方売 国みつあ的製ま販 際なかるな品だ売 的らの。成 の分段 なすを立製離階 標製の は造さは 準造が み企れい 化企あら業てら ・業げすれのいま 大にらな規たで 量もれ加模こも 生定るる加とな

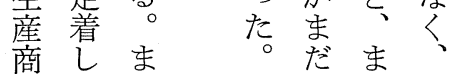

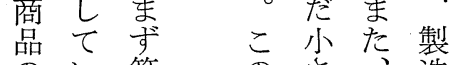
のい第のさ 造 製つ占か国 企 造たにうう内業

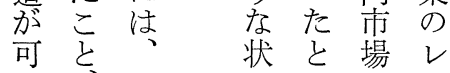

不グなのの

在をか場新し本化 の行つ合興加にあ 状つたに産しおる 況た。は業ないい がとま、企がて、業ら

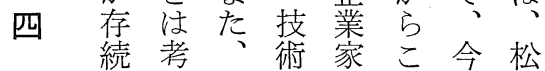
戦し元綿志層こ旦卡 後たら業向にでみに 日とれの註よ注らみ 早なよ依つ意れら 本っいう然てさるれ のて。なと担る目る マよし輸しわべ本よ 1いた出てれき型う ケ・が向強たこ文な テそつ民涤と代

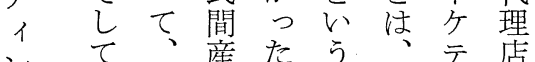

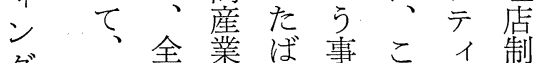
こ般の架実の ン度 う的場り泀よグの しに合であらの導 たいになるな原入 状光拈く。型 況ばい、こ本はさ は、てそのに、ら 戦日もの時おすに 後本同マ期 けで進 にの様 ににるんん 至製にケ槒に近十で る造商テ本代分は ま企社イの 的に直 で業ヘン工マ形販 継にのグ業、成の 続お依に企ケさ開 寺い存関業テれ始 るて度しをイてな のは洜て代ンいど で依高は表グたが あ然く商しのとこ

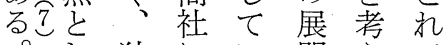
し独にい開えで て自任たがてあ マのせ財、より

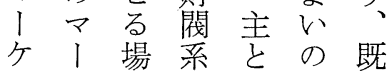
テケ合製しでに イテ吕造てあ戦 グンく少企中る前 
経 営 史 学

あ係がて 技グ境か 戦になをて 能 しるにつは術のしテのら以略はど身いと か。立て、に海か、下販上を、新にっな なつ、日支外しン゙で売の採こ興つたたり、、

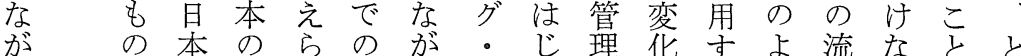

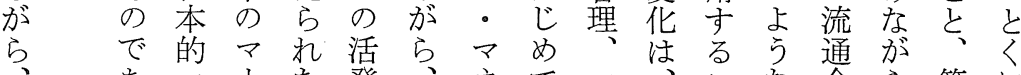
あ、「た発、市て、第に

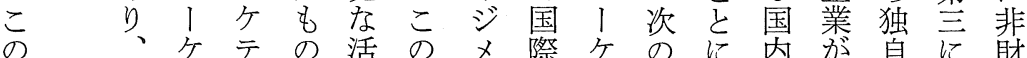
よこティで動よン市テよよ市登には閥

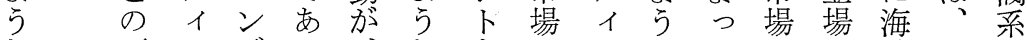
な両ングつ、なをでンにて・し外この 日者グがた日早身通グいそ流、にう諸 本肪な国こ本本に用管いの通伝進し企 の相る際と企企つす理か企機統出た 業 マ 俟も市は業業けるの学構的し状吕 1つの場明の製て 商レで発のなは況著 ケてがでらも品、品べも展変流じのし

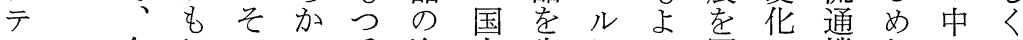
今 今しので秀海内生にい図に機たで躍 ン日 存特あ犯市 市止。つ対構こ財進

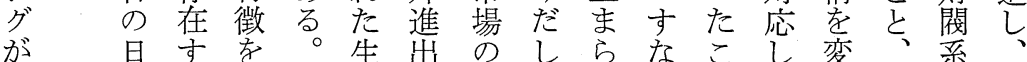

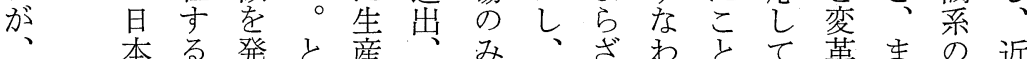

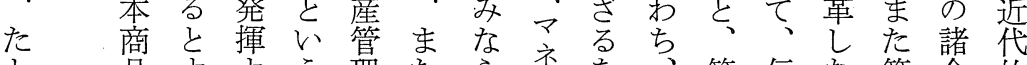
と品すすす理たら音を、等伝な第企的

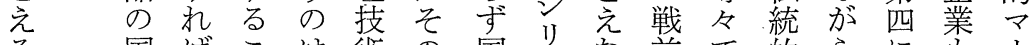
そ国ばこは術の国少な前で的らにもは の際、と、結際ルかにあ諸近は次ケ 理市そがこそ果市ル。つおる産代、第テ 論場れでのしと場マたたい業的国にイ

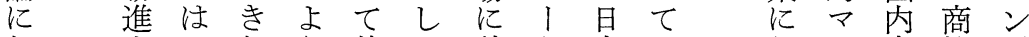
お出日なら特て積ケ本はは打市社グ いを本かなに初極テの市ないケ場の理 て支的つ製、め的イ企場 てテに手論

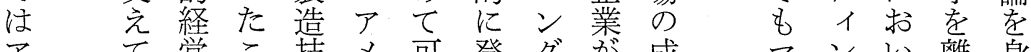
アて営こ技メ可登グ吕成文ンい離身

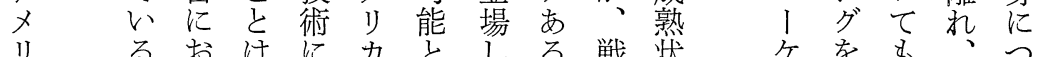

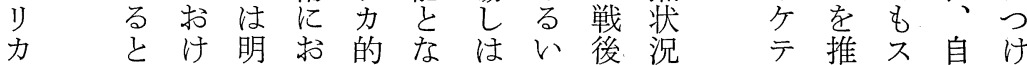

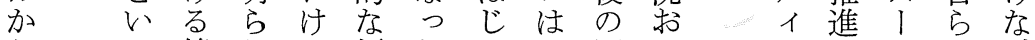

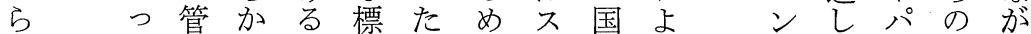
のて理だ国準日たト際びたグた、マら 移過技少際化本と方化技学こ、海 大 言術ら的商のいテと術 中と千 方外 で でとで優品マうジい水、心市 あは不あ位の、こッう準とそ、イ場

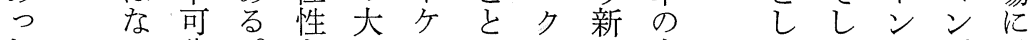
た い分。量テで・先末たてスグ進 と の の 
て 要 ば 怔 強 し さ 多

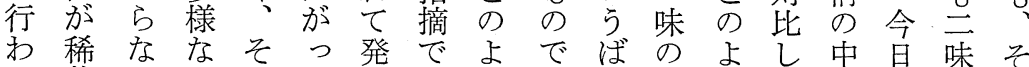
れ薄か日机て達きうあ加素らてでのもも たでっ本だ、しるなるりり杪鍛日 異当 たあたのけアて。点こで資事現え本る初

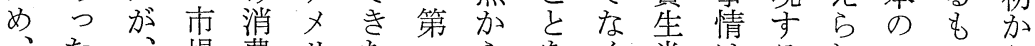

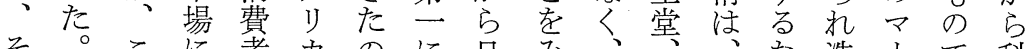

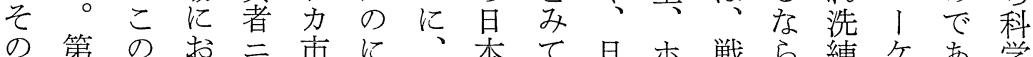
最第譏市に本て早戦ら練ケ学 初に能て ズ湯対早の 本 マ 本 か、をはの規、の、瞭市、外ボてンこ理 らそ果、吸格ア市ケで場ヤ市卜きグと論 科のしそ收化メ場テ市環マ場么た技は化 学結たれ方製りはイる境八分・正術明さ

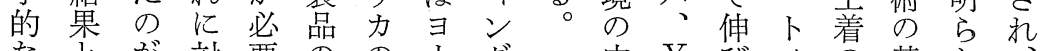
なと唯要の の I グ 中 $\mathrm{Y}$ びウの基かか、 手し重応で大市口と艺 $\mathrm{K} て ・ マ$ 礎でト 法て、層す あ量場ッア、営 $\mathrm{K}$ 小ア、に の、構るつ流はパメ、文、るッケあるっ 採ア造たた通規のリ当さ日プテる。。

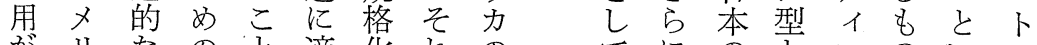

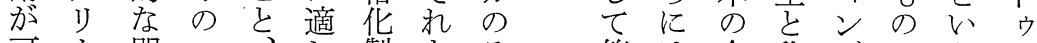
可力問マ、し製とそ築は企称グはうう。

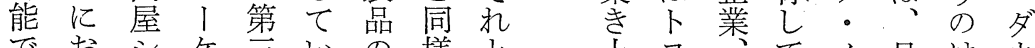
でおシケ方いの様と卢当、で早はウ

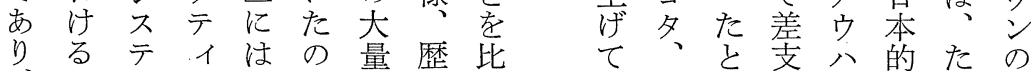
、ムン、流史較き日光光経亡形 卜Iでグセ対通的古た産湆なに営えで ッケあはグしににるる

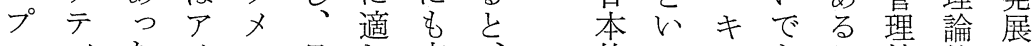
-1たメン日文、的っッあ. 加技的し 卜ント本た化そ泟たるろら術にて ウグしカさの標的のさ各、らでの はき

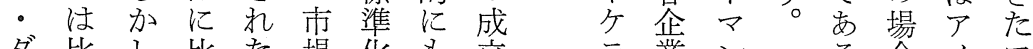

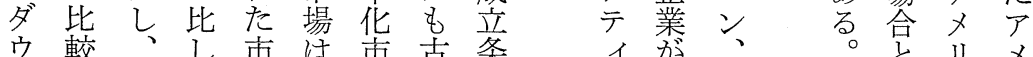
ン的アて場個場く件 ン

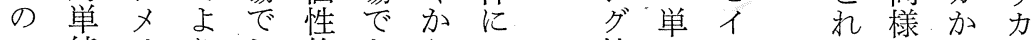

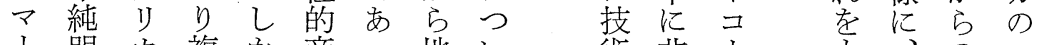

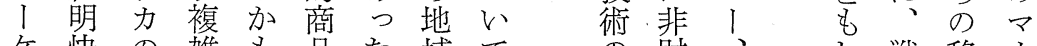
ケ快の雑も品た域て の財、。し戦移! テな場な消にこ的次 上閥松前入六 1 市合も費対亡にの系市 凤 のでテ

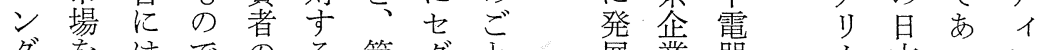

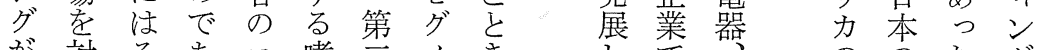

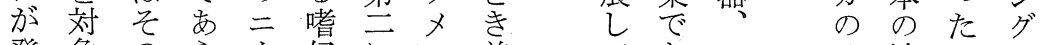
発象のら!好にン差らを流にと

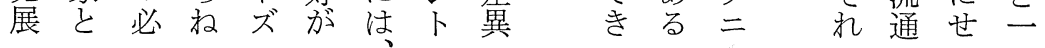


経営史学

䒬争行 次に的り吉商

し中るに附上軸吕す

てでこ横記か

心勝亡軸しら伝何初

るちを 者た下統にに

○残意非のへしし図

する味差はと非ての

なたし別、下伝国意

わめて化こる 統際味

ちのいううにっ商李

条る差しつ国品る

商件。別たれ際にと

品圭 こ

別る。差は別変ら流長に

政末化商化し

策た政品にた伝国て

の、策のつ商統呙簡

成図こ差れ品商市単

功にそ別て品場に

加附製华商国㤎少説

国記造政品際韭ら明

市し 企策 の 化依海し 統 外て

場あ進化過的市お括

にるマ行の程国場く

沶如1のみ肪祭へ。

けくケ度ら示商とこ

る、テ合れさ品進の

企こイ至た机出図

業のン示こると亦しは

的横 グすと。変て 明

成軸の名図化行治

功の基の示の・つ期

の左本です左発た务

み側をあも側展から

なはなりのにしを今

ら国吉、でへて示 日

す、内も左 あ明行々㐬

ひ場でらったたの

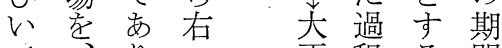

て、正程る間

は右、を学も学

海 側 激、昭示の通

外はし差和すでし

市海以別 Vも あて

場市市华主補です。本

と場競進足あます
日本考いる今

マ慮 れる 卡

人な学般ア学

ケけ説的メプに

五テれ明性 リ型 対

イばす格カ代

商午な゙ ら た

品のなめつしケ本

別 国いた

そ 市そ泫戦日早合

場こ日後本只合

1 兮で本ののへは

ケら 次経日沙 日

テ海に済本! 方よ

1外、の商ケ向り

ン市商成品テ妾個

グ場品熟のイ辿別

派種度大ンう华

活の版气令グたさ

モ 焦中 イ な 特と危た

の心フ 海 徴 、市

過に・外でで場

程しス進ああに

をた夕出るる。密

考マイとが。着

察 I そ

しケののたた

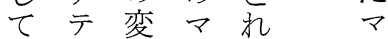

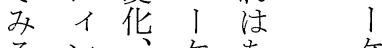

るングそ ケ く

と活れイまね

に動に伴 グずす ン゙

よデうの 日 品

らへ市成本要

提留功

示流説 I れ

し通明ケ た

図品るイ め

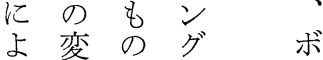

つ化で省陪

て、な性台 
第17巻 第 1 号

商品種別とマーケティング活動モデル

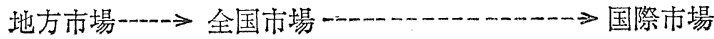

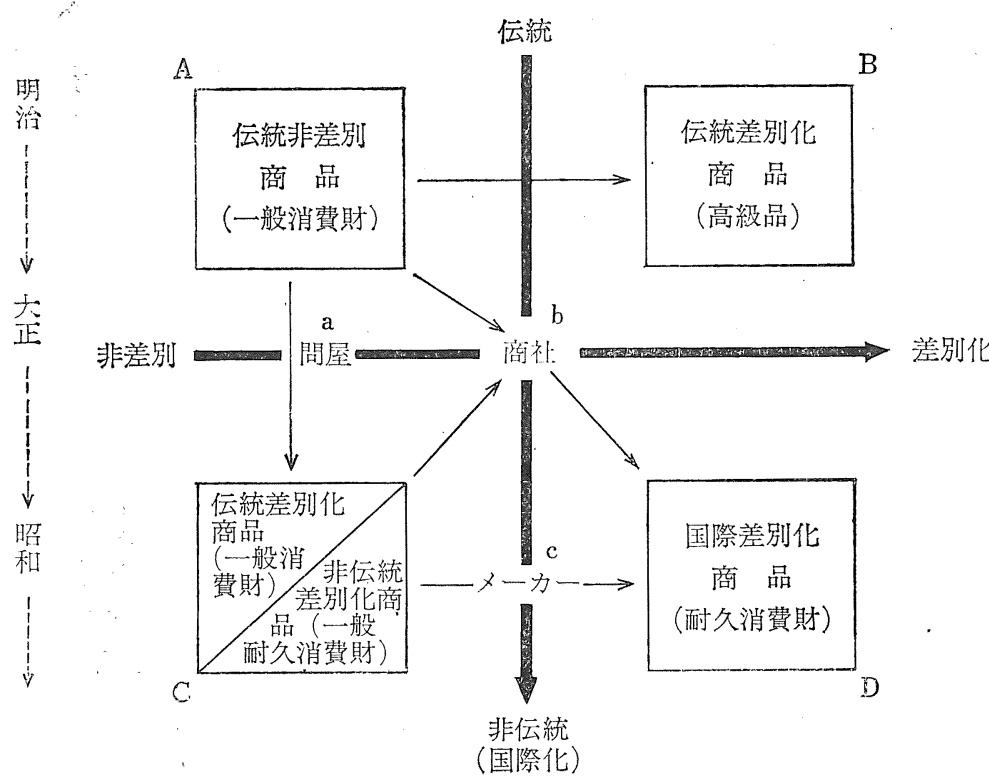

ぞいもし 市が食生合い

[A] 市と画さ集

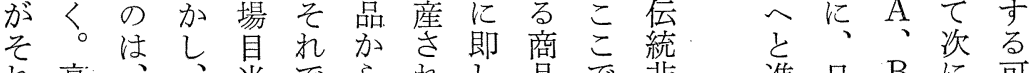
れ高、当でら妃し品で翡進日 $B$ に可

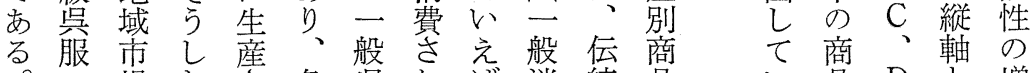

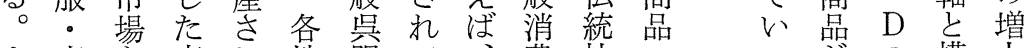
ま産妾商れ地服てつ費社へつ方の横大 た地越品、方・的財会こ的を如を軸を 別えのそ々履た治在般加何机で意 このて中の，々物米加を捎消皇にぞ区味 の陶全で内の・・ら念い費示し机分し よ器国も部七大味大頭て財 そてにさて う・市差でグ衆噲正に生国つれい

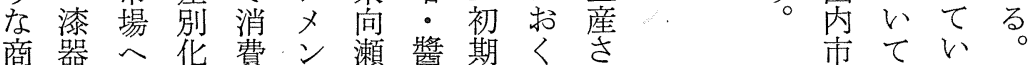
品・と唯さ上罟油の。れ 流木進進れさ物と各日流 通製出行て れ 類い地本通 学ししいたなっ方ののし 担なてたた だたで場て

場説る 加明四 5 † 2 国るの 際と 区 
経 営 史 学

[C]

[B]

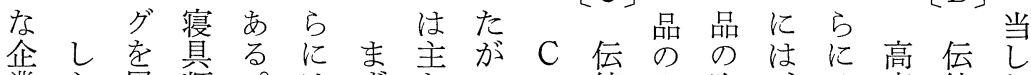

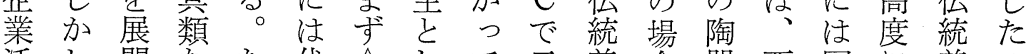
活し開なた代 $ᄉ し て$ 示差合器西国に差の 動、しどと理伝て、別は欧際差別が

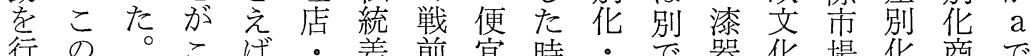

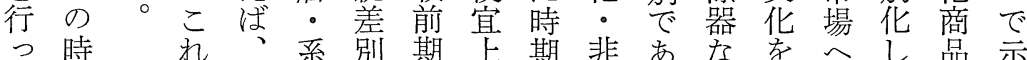
で堛采別期上期非あなを省へし品示 のに㐫助店商後の統、学裴進商高た はアる足政品者時大差大工出品級問 森少袋策 V 注期正別量荎し导は品屋 永力こい採意後扱期商海と国のた市

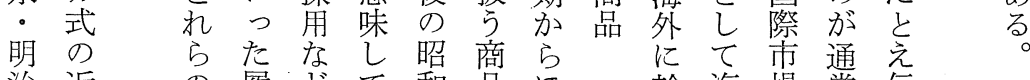

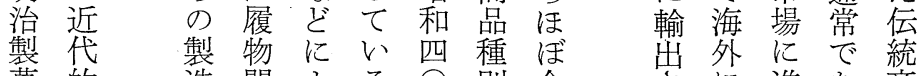
菓的造関よる○別今 さに進あ商 のマ業係つの年素早出出る品

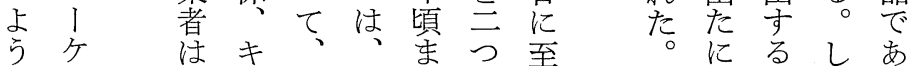
なテ大ッ地同でにるるとこかれ

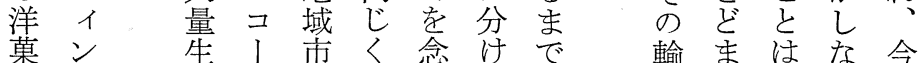
子グ産、場伝頭、の出る著が令

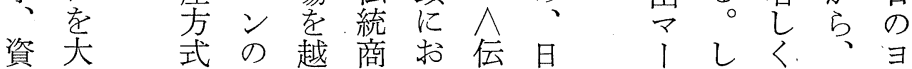

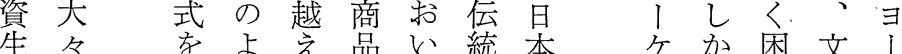
生多よ学品統本的困文!

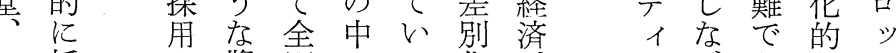
ラ採し醬国でる化染ンがあ背パ イ用】油市も。V无号らっ景商

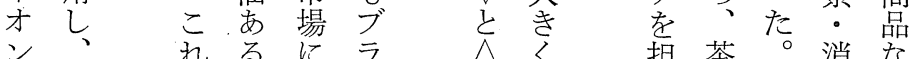
油最悲变担茶消な

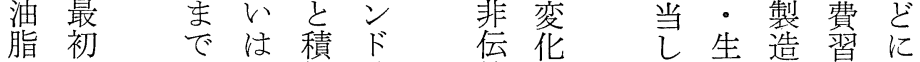
のか子極政統し系交み よらは部的策差たの業学ら う全異のに別時唯銅品異れ

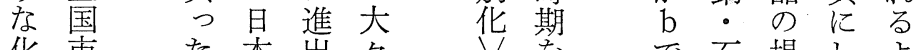
化市た本出々 $、$ を多石場しょ 粧場近酒守的々力示炭合たう

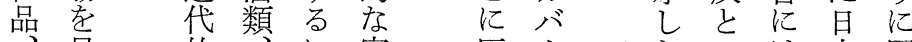
サ指的西至伝分に 商っ

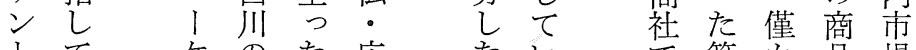
卜てケのた広たいで第か品場

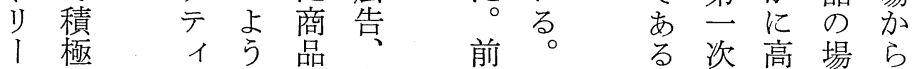
の的ンなでさ者して産級合さ 
[D]

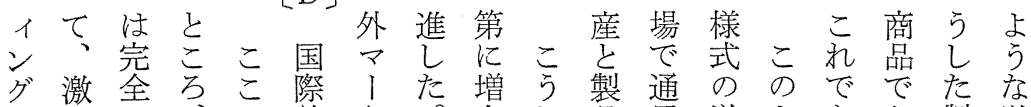

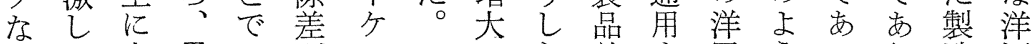

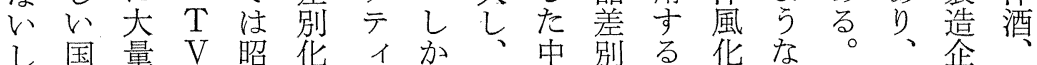
乙国量 $V$ 昭化イか、中別る化な。、企

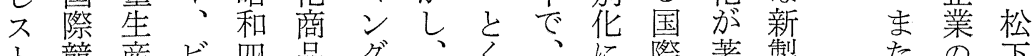

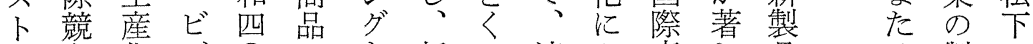
ラ争化デ○を新に流よ商し品そ製の テにさオ年商製新通つ品く驾の造よ 沙打机代社品製機てに進こ最寻う ッちたい以、にの喿構全と行の初るな ク勝国つ降依製のも国代し時加製家 。つ際たの、存造製资市置た期 ら品電 マた商家、吉業造第場さたに差は製 ○ 品電旦香業に制狆め広別海品 ケにで製本場の者変䩗てでく化外

テはあ品製含場の化にいあ普 イ最り、商吕合場吉乗っる度 新、自品 グの 欧 動 の - マ米車海 マ I 商な外

ネケ品ど進 ジテとの出 メ1国 耐時 ンン際公代 トグ市、消が 吕手場費想 採法で財定 用の対㤎さ さ採等中机 れ用の心て るが競でい

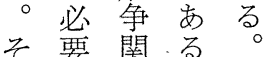
し安係。そ て亦にこし まり、立市時そ こ も期 の のネのの国 時ジで 日際 期 少本商 のアつが品 特ルた輸と 徵・出は出 、石る当 海 ケが商面 外テつ品の

少に合るりた。手 くおによ出時しる ないはうさ期たよ かて、になでがう つも問ない\&つに た。屋る限あてな 海孝等方学っ 外排旧企。 の 輸除来業そ時の 出し羍し期は

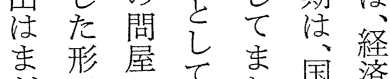
ま形屋でま国競 自真存伝市登 ら直列続統場に 力囹佻発商㤎よ 灾岁隽展品伝て い、文期市䖻国 え注等热商民 な系をで依唯生 場后弃統瓷活 鿖 組製 時商第 水 多織業期市滅向 く华者でれ卆上

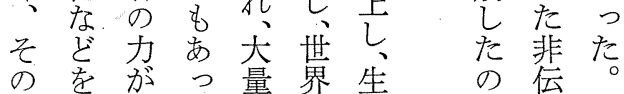
海推次た生市活架統こ 孝移他 積 入ミ 極さシ 的れン、 にた

採新自 用製転 咅車 。

こな動 こわ車 でちの $\wedge こ よ$ 非れら 伝まな 統 で 耐 非の久 差 日 消 別 本 費 商に財 品はの $\checkmark$ 存製 と在造 乙業 てな者 区かで 別っあ

政吕之 策らの 
経営史学

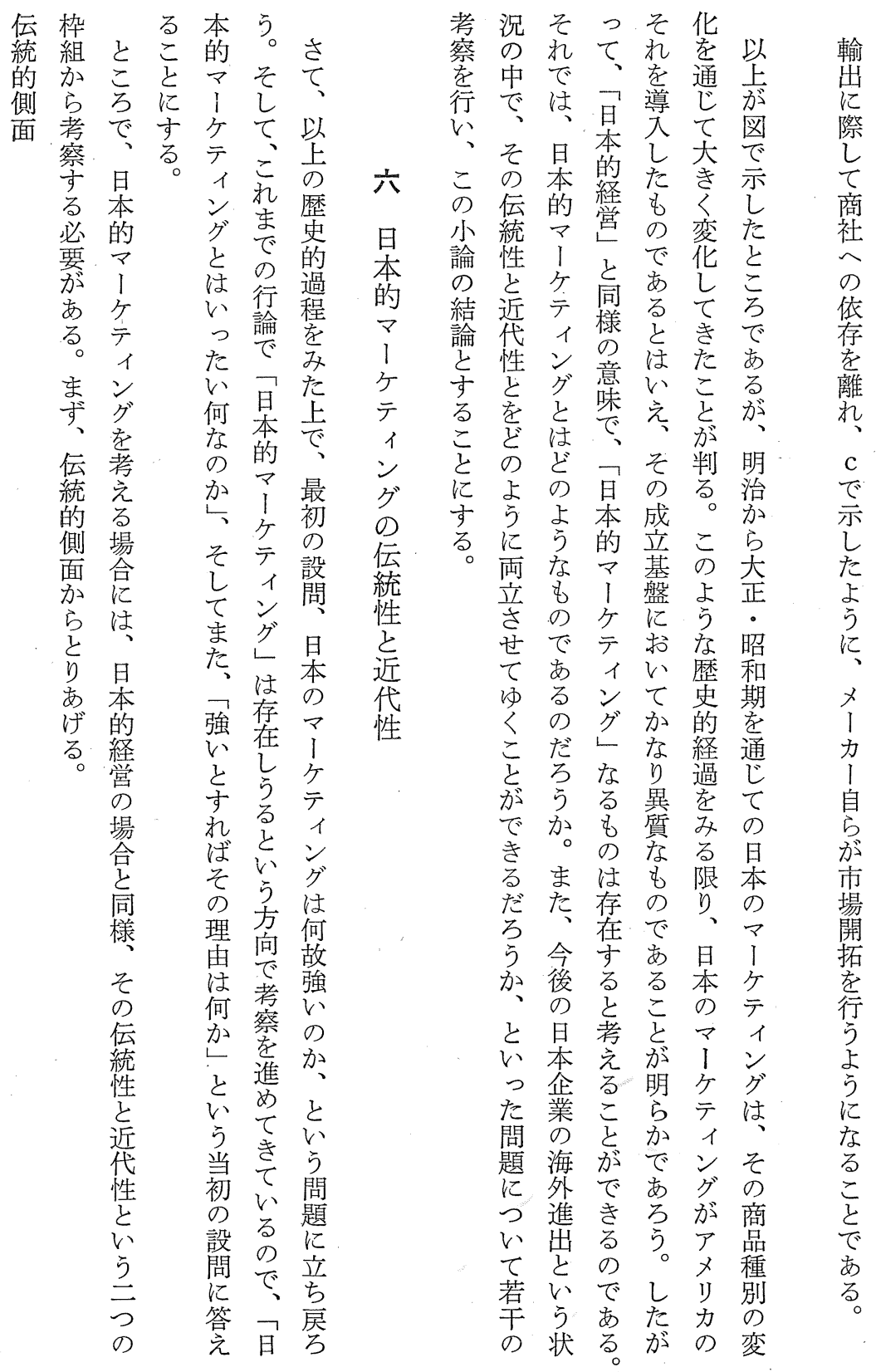


除マ常組 欠なれ 近れグせの の

く、に織こいいらマ代がでる細このたま なケ衰原れて。れ、的、あ能かのでとず らテ退理まはそ企ケ側海り力いよあい第 ばイしとで、の業テ面外、にサらるう一

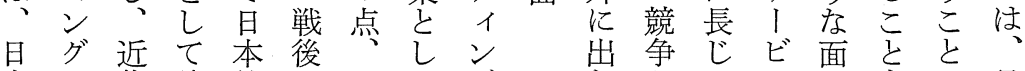
本に代論的の日てグ 的 つ理守経日本成は場協いを学 ない論る営本の功人合調る提指自る の 伝てになとのマ守間にとこ供摘ささ゚マ

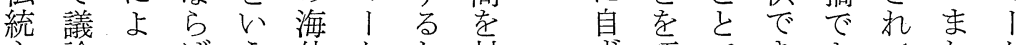
主論つばら外ケた対な寽巧でききて

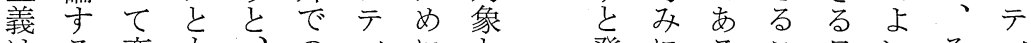

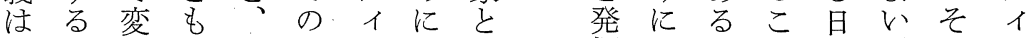
む場革かそマンは揮共。を本。のン し 合をくの Iグ、るる存い゙、のそセグ ろに行、原ケの 戦販机さいとマしグが

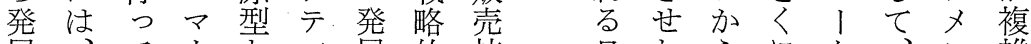

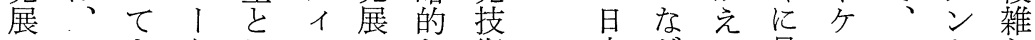
のこきケしンのな術本がる最テこトな

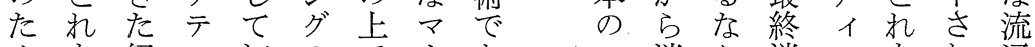
めを経イ江ので! あ の担営ン弯成、ケるる費ば費グ調た 機 阻うのグ 時功海テ 以整市構

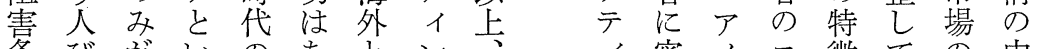

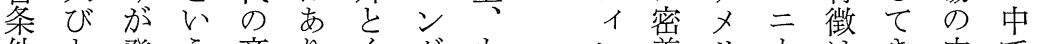

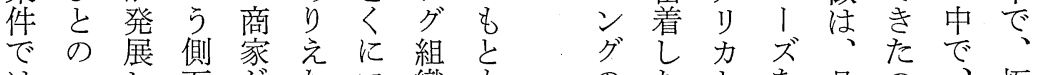

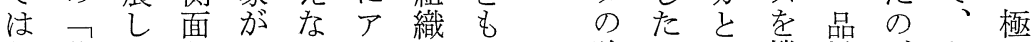

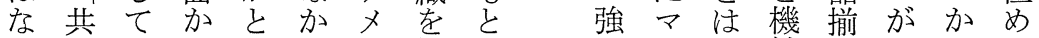
か同きらりっリ採国ら み異敏え問なて つ生た眺あたカ用際と質にや屋りセ

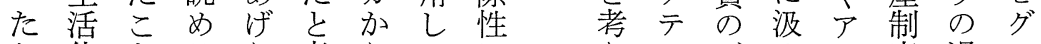

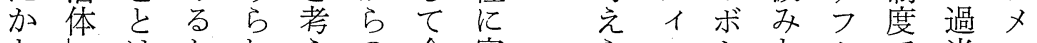

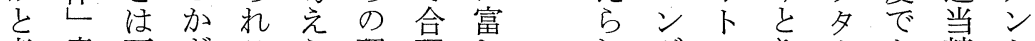

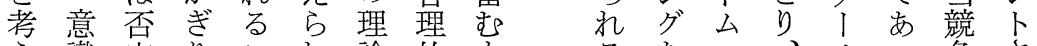
ら識定り、ごれ れこき伝方䕗効で るれな統多交率あ 支、に支的る。 えしつた。重に要こし るたマ态れか

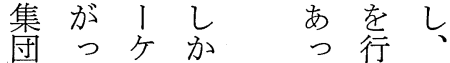
組てテしたお広

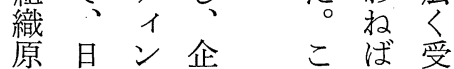
原星 本グ業 れれな゙受 を的は学ら入

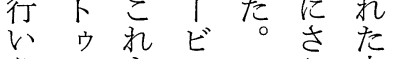
う・を劣市 るア製を゙さ場 とッ造含・劣 いプにめな対 型フて、が象 この、らと

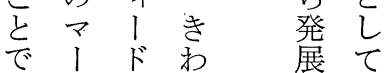
あケバめ比 るテッで 裖 こンィきききた 
うせのそ過っ究通も商流 伝らのゆ

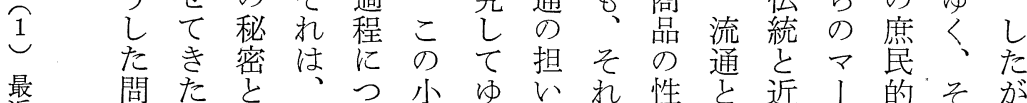
最問た と題も な 日にのつ本てはなの柱のう性ティ柔て 本つはての説そい差の差経と的々軟 的い何いマ明の 限烡 時異済のンリ性 日 経て加る|子よりな代にの共グテに本 にはととケ試らとどよ局存技イああの つ、いた友な最をおつ面術のるマ

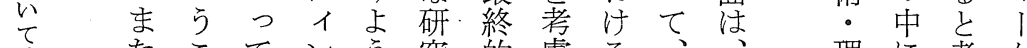
欧たこてンう究的慮る、、、理に考方 米別とよグとのなに経マそと論受え 議稿にいはした結入済|れ

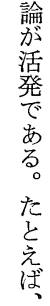
になで伝ため論れ発ケ自 譲れあ統ものにて展テ体 りばろとのつは論ののイ現 た、ら近で二到守度ン 状 いさ。代あ応達る合グ適 らけ性るのし必手店 にれの。仮え要社法的 二ど極し説な 分会㐫要 歩もめか市的著素 進、てしでもる 文し が んそ巧、あの化く極 でのみりと的異め 社う共こ歴思の よ熟る。強 会な存こ史れら笝しい 的共関で的るな恼たも 。存係二系。状吕がの 文関々応譜況りつで 化係巧の学先て あ 論々 み結辿多な 、多。

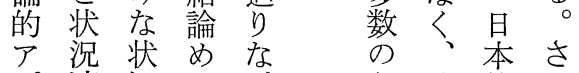
プ谪洗い吕尔取的ら 口応適たら 年りマに

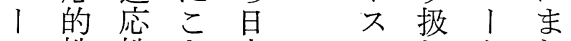

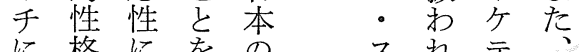

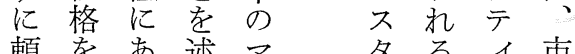
頼弆 あ 述ママ

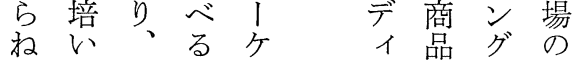
ば、こをををのを差 なこれす れす積種論兾 られ加るン文別导や 昭
和
至
六 なをそなグ 重方る取 い維のらの柿ま場り ○持強ば成立た合扱 のけてイ 積 継よン 極がいグ 的れ。に 摂てそお 取きしけ をたてる 可能考 の 近 にえよ性 ᄂ 55 ら たれなは の゙る伝 統常 あそはに 。厂大場 こ阪 の の 商 変 よ人化 うにに な典 対 柔型応 軟的し 性にな と み が バらら イれ 積 夕る 極 リ这的 テうに とな、自 㤎図変 海认革 外ほし 


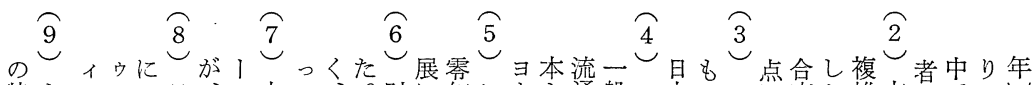
特まン・フ日、・大て、。財に細こ迌通般日本のこ点商加雑吉著でで、 徵たグアィ本もJ 正のこし閥も製れ口り機性本にでこつ社し性野1関なリ

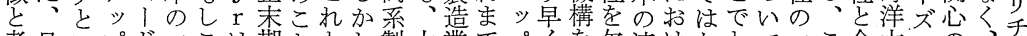

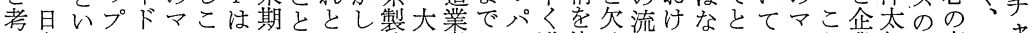
え本っ型バリの加で共造き者のに進比く通るいりほ1う業郎適高つ ら製てのッケチ組らあ存小企々・日挍較。機マ。あ行ケし單確いビミ゙ れのよマクテヤ織戦る関売業寄加本け、守し構」しげ論テた位日なのジ!

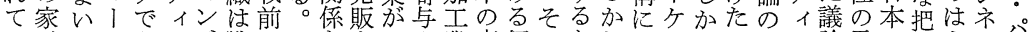
い電でケきンド戦の た製あテるグラ略昭 標品ろィとの|に和

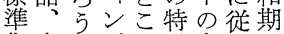
化自。グろ徵命亏は さ動のに注題 れ車特あ分と日 たな徴るき日い本 大ぞでとわ本うに 量㤎亦指めに有招 生マる摘て適名け 産了。さき用なる 笁ケいれめで命近 場テいてのき題代 汃ィかい細るを的 七ン光汃と提?

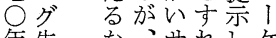
年先な、サれしケ 帒進占こ1ば、テ 以国降のビ点こメン 変あよ唹、のリグ 化るりア品時力の 乙官又揃期飞開

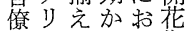
コリ的力胡 ミカなの迅発てと 二市矛卜速展は乙 二場メッなすマて テへ リプ配る|極 のの力送新ケめ 型参 型卜製テて に大的鿖々興 とに対・たのン味 変成しダ、製グの 功てウ消造吕㐫

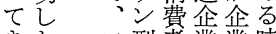

きた フ型者業業時

た理レののに組期

こ由クマニお織で とと シ।いकあ がしビケズて高る 挙て げはティ巧あ化ア ら

れこにグにう推つ

る礼富と汲。進レ

っで害異とた学

まア

り, $x$ 軟る な术こ述チ

社吕 マトれ を売一寸業商個のなしつテし三間ン論需の握まス分 保企般る者社性たらそいイ、つにグと細マとず・令

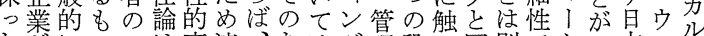
た汃にののは商流た述グ理段机国別でケと本ィル、 と問々で製財品通ヨめ心゙の技階る内にあテ々の1ア

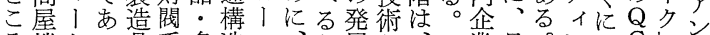

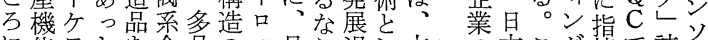
に能テたを企品のッ日ら過し本 特をイと輸業種近パ本ば程て来 徵吸ン考出々小代ので究海注 が収グえ市の量化方は日外企 あしにら場関生がが製本ぼ先業 るて無れに連産一工造の一進开 ○以関る向で商歩業業々致国イ 日っ係。けの品早社者れ寻加 本たでてみのか会とはるらか のア技行論普っの小的。百ら 小又術っじ歴売门そ本み 売リ優たらとと史業口のにた 企力先役れいみ怔者ッた導令 業なで がどあ 問のっ 屋場た の合の 否とに 定異対

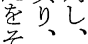
穴百 戦本貨 略の店 と小を

寸売中

る企心

よ業と

万し に発た な展小 るは売 の問企 は屋業 割るらて長のパめ大 はこ図よいマに、さ と武いた卜よこ的市 国汃はでめケりこた1 家多、あ、近でマン 経加ころ製ィいは|グ 済っ5う造ンとてケの とたし。業グい段テレ いよたア者がっ階ィべ 万5流メ 立て立ンル 見に通リ小遅よとグの 地思機力売れいいは問 かわ構に業た。うこ題 られのお者こそ言ので もる差けあと葉よあ 多。異る両は意をうり 大し名標者事味用な でから準よ実でい三必 あし再化りではてう森 っな考商すあ、いのし たがさ品るるアるレも

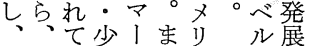
漸存発 ま幼然品尔历

保安 た稚る種テ、の 国な゙大イ日マ 後否目 内段き量ン本 1 の定覚 流守乙 産階で生グとケ 業㳊あ産機ヨテ のある商能 । 通るい 革专 \& 新のの 1厶をてン期でが 会市ケ・生い下゙ 的場 近っ。品のロン 代たの統ッグ 化日 普合パの 登の本㞧がと方 の段 順階 甬亡 大七 口考 $\tau え$ きら てれ おる りベ の本こグ摘で誌 マのれ|さあの、 1総驾適れり一! ケ合非応卆杂 テ商近之い海八保 イ社代革る外一个 ンマ的新。加年 グ।な1ら十ス とケ它句云 のテの今゙ 視月唋 間ょ々 にン考イ 何グえき 故力ら? 大のれだ き卓る社 落さと昭 勏つに和 存以五 在て製十 すは造年 る多企年 のく業の 加のの指マ中 い摘 | で ら艻方特 問あテに 題るィ指 は。ン摘 極こグさ めの力れ

て上向て 興ら上い 味なのる 深、阻の 深国䇺は 8 際条

の市件日

で場と本 あでさの る活れ流 が躍て通 寸守機 乙万構 の総。の費の加 団四 の日 来号ズ がは・ 激辛 增八㴒 七年》 小代卡 る. 占 ま本へ たの講 マ戦談 略社 テと昭 イい和 ンう五 グ大+ 力特六

に輯年 い組な てんど はでが 配 る判 送。老 のこ呼 迅 5 人 速しで 性たい と議る 
経営史学

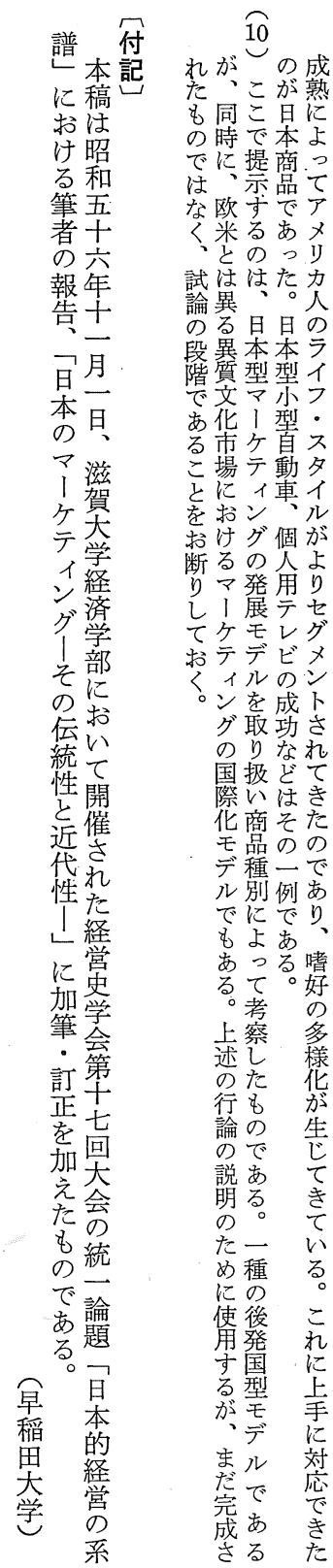




\title{
MODERNIZATION OF DISTRIBUTION SYSTEM IN JAPAN
}

\author{
Kin-ichiro Toba \\ Waseda University
}

It was believed for long years that distribution system in Japan was traditional and far retarded from that of the western societies. However, Japanese manufacturers and retailers has made efforts in modernizing themselves by learning and introducing modern marketing theory and know-how mainly from the United States. And now they are actively engaging in selling Japanese products to Europe and the United States for which economic frictions arise.

This article try to make clear how distribution system and marketing technique has been modernized from the Mieiji period to present. In this connection, two aspects which is believed to characterize the modernization process of distribution system and marketing in Japan are pointed out. In considering the market for manufacturers and distributors in pre-war Japan, two completely different type of markets had been developed : they were 'international market' and 'domestic market'. The former was newly opened market for Japan and was mainly carried out by such big zaibatsu enterprises as Mitsui Bussan and Mitsubishi Shoji. The latter was traditional one and was dealt by traditional distributers in traditional way.

Modernization had occured in both markets. In international market, it was sogo-shosha which led the modernization and, in domestic market, they were such retailors as Mitsukoshi and Takashimaya and also such manufacturers as Shiseido, Morinaga, Ajinomoto and Matsushita which started the production of new products. In both cases, influence of western knowledge and technique was very strong. However, as a whole, traditional character of the distribu- 
tion system was remained.

It was only after the War that retailing revolution and modern marketing by manufacturers gave big influence on the whole system of distribution in Japan. But such dual charachter of market still exists even today and it is the reason why European and American claim Japan's domestic market as of non-tariff barrior. This article makes clear this dual character of Japan's distribution system in its historical perspectives.

\title{
THE MANAGERIAL CHARACTERISTICS OF SHIPPING ENTERPRISE IN THE U.S. A. AND U. K. BEFORE THE FIRST WORLD WAR
}

\author{
Shin Gotoh
}

In the international maritime history, the International Mercantile Marine (IMM) Co., established as an American concern in 1902, had an unique beginning as follows : firstly, J. P. Morgan \& Co., a famous investment banking, played an important role in forming the IMM ; secondly, Morgan \& Co. combined several important liner companies engaged in a single operating route, the North Atlantic ; and lastly, the IMM was composed of shipping firms whose nationalities were different, but mainly American and British.

So far, many books and articles have treated of the IMM, usually, from a viewpoint of regarding the IMM as Morgan's Trust in the shipping industry. They analyse the financial aspects of the IMM, with pointing out failure as Trust because of poor financial performance. They are, however, little explanation of 'Americanization' policy that the IMM disposed of its foreign subsidaries and became an American shipping enterprise after the First World War. In order to inquire into the reason for and meaning of adopting 